\title{
Theory and practice
}

Theory is usually assumed to precede practice but 'Practice preceding theory' is the telling sub-title to Patrick Hodgkinson's essay on Leslie Martin on p. 297 of this issue. It is a full year since we published an extended celebration of Martin's work together with his essay ‘The grid as generator' (arq 4/4). Kenneth Frampton's subsequent Postscript (arq 5/1) placed Martin in a historical perspective. Spurred by Frampton's assessment, Hodgkinson now reminds us how Martin's later theoretical work can be said to have had its origins in the studio's early work.

This thought-provoking reminder comes at a time when, in the UK, architecture's standing as a research-led university discipline remains as low as ever. Once again in the government's recent Research Assessment Exercise no architecture school achieved the highest rating. This was unremarked upon both by the professional press (which was much more interested in the upsets at the top end of the leaguetable) and by the RIBA (which probably hasn't even noticed and has certainly never grasped the significance of university research). It seems that neither much of the 'theory' which so many architecture academics expound nor the odd bit of practice that they manage to undertake is highly rated by the assessors.

This, of course, is not the outcome intended by the 1958 Oxford Conference on Architectural Education (master-minded by Martin) which determined that in future all architects should be educated within the research-led university system. But does the RAE debacle matter? It certainly does. Research-rich schools are better resourced - and that benefits both teaching and practice. We need to take a hard look at why architecture fares so badly - and to question its grouping with construction management and surveying. We must also consider the very nature of universitybased architectural research. Hodgkinson is right when he concludes, 'much thought still needs to be given to architectural theory if it is to raise itself from being purely academic - and therefore practically useful.'

But take a look, too, at the articles on pp. 305 and 312 of this issue. The first, by occasional practitioner and academic Peter Blundell Jones, sets out the case for 'Working with the given'. In the second, 'New meanings from old buildings', Blundell Jones and another practitioner/academic, John Sergeant, appraise three very modest house conversions and extensions designed by them and by David Lea. These architects have evolved their position over many years - developing, through building, discussion and writing, a genuinely sustainable approach to the use of resources. Their buildings may be modest but, together with their writing, they eloquently encapsulate an approach or theory that is increasingly relevant - and utterly practical. 


\section{architectural research quarterly}

\section{Subscribe now for 2002}

Innovative in conception, unique in breadth and generously illustrated, this pace-setting quarterly publication from Cambridge University Press links, on a global scale, the worlds of architectural practice and research. arq regularly includes extensive peer-reviewed sections on design, history, theory, construction, environmental design, information technology and practice - as well as structures, urbanism and documents. These are supplemented by letters, reports, reviews, a directory of specialist research centers and consultancies and an annual index. Each issue opens with a leader and closes with insight, a personal end-piece. In its three year history, arq has published work from all over the world: from Chile to Sweden and from Japan to the Netherlands - with a strong representation from the United Kingdom and United States. arq, like architecture itself, is all-embracing and written by and for both practitioners and academics. It provides an outlet for all those who wish to disseminate

their work to an international audience.
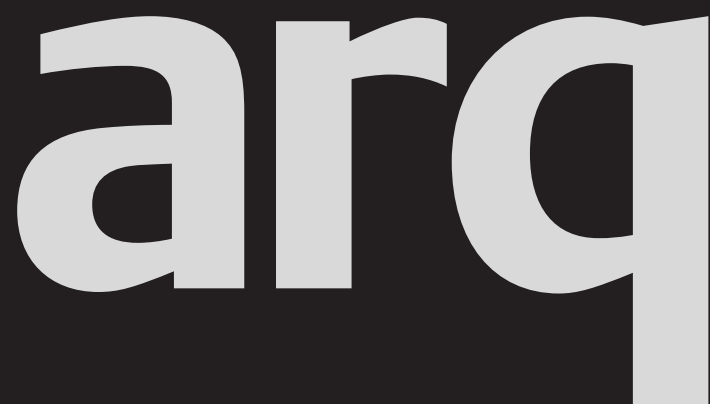

Please enter my subscription to

arq: architectural research quarterly, volume 6, 2002

$$
\begin{aligned}
& \text { £110/\$174 institutions print and electronic } \\
& \text { £28/\$46 students } \\
& £ 41 / \$ 63 \text { individuals print only }
\end{aligned}
$$

EU residents only. VAT may be payable at your local rate if not registered.

Our VAT registration number: GB 214141614 If registered, your VAT registration no:

Total subscription payment $€ / \$$ Eu residents only, if not registered add VAT at appropriate rate

Canadian residents, add 7\% GST \$

Total $\mathbf{E} / \mathbf{S}$

Name

Address

\section{Payment enclosed}

Cheque in sterling or US dollars

(payable to Cambridge University Press)

Credit Card - VISA | MasterCard | American Express (delete where applicable)

Card no

Expiry date

Signature

Photocopy this page and send your order to:

Journals Customer Services, Cambridge University Press, The Edinburgh Building, Cambridge, CB2 2RU, UK

$\mathrm{T}+44(0) 1223326070$

F +44 (o) 1223315052

E journals_subscriptions@cup.cam.ac.uk

or in USA, Canada and Mexico send to:

Cambridge University Press, 40 West 2oth Street,

New York NY 10011-4211, USA

T (914) 9379600

F (914) 9374712

E journals_subscriptions@cup.org 